\title{
The Role of the Family Environment in Building the Environmental Care Character of Geography Education Students
}

\author{
Fitria Mustika* \\ Faculty of Teacher Training and Education \\ Universitas Samudra \\ Aceh, Indonesia \\ *fitriamustika@unsam.ac.id \\ Nurhaslita Sari \\ Faculty of Social and Political Science \\ Universitas Teuku Umar \\ Aceh, Indonesia \\ nurhaslita.sari@utu.ac.id
}

\author{
Rahmiati \\ Faculty of Teacher Training and Education \\ Universitas Samudra \\ Aceh, Indonesia \\ rahmiati@unsam.ac.id \\ Fadilah \\ Faculty of Teacher Training and Education \\ Universitas Samudra \\ Aceh, Indonesia \\ fadilah@unsam.ac.id
}

\begin{abstract}
The family environment has an important role in shaping the character of the environmental care character of students. This study aims to determine the role of the family environment in the formation of the environmental care character of teacher education students. This is quantitativedescriptive research using the survey method. The measurement in this research is the label scale. Data were collected through literature study, interviews, questionnaires, and documentation. This study uses a percentage formula. The results showed that there was a role of the family environment in the formation of caring character for the student environment. The percentage of the role of the family environment was very high, with a total score of $91 \%$. Therefore, it can be concluded that the family environment plays a very important role in shaping the character of caring among students.
\end{abstract}

Keywords—character, environment, family

\section{INTRODUCTION}

The family's position as one of the informal educations is vital for the continuity of education for the nation's children. A family plays an important role in the ongoing process of education and the formation of children's behaviour in accordance with the character values that exist in the community. The real implication in life is that the success of character building does not merely depend on school but also family since children interact more with their families at home than in formal schools. Therefore, the role of the family environment is one of the main pillars to shape the personal merits of children so that they develop well in ethics, behaviours, and morals [1]. Building children's character requires a great level of patience because the current development of globalization not only has a positive impact on children's knowledge, but also has a negative impact on children's morale. The decline in students' morale in the current era of globalization can be seen in many aspects of life, such as disposing of garbage inappropriately, neglecting social activities, using nature that is not environmentally sound, and not caring about the environment. This makes the character of students as the successor to the nation's generation worse. Hence, there is a need for guidance and application through the family environment as the main pillar in building a caring character for the environment. Therefore, the tendency to build a caring character for the student environment starts from activities or habits carried out in their family environment.

Students as the younger generation should possess the character of discipline, responsibility, think critically, love the country, work hard, and care about social life and environment, to make the nation's children excel with positive characters so they can compete globally. By building the environmental care character, a clean, beautiful, and cool environment is created. According to Purwanti [2] environmental care character education is the embodiment of human attitudes towards the environment in the form of actions in daily life which are an effort to prevent damage to the surrounding natural environment, as well as trying to improve all-natural damage that has occurred. However, the environmental care character for the nation's children is currently being neglected. The attitude of being selfish that they carry out in various activities that can damage the environment is ultimately far from environmental care. Building student character is not only the 
duty of lecturers but also the family environment who plays an important role in building the character of student concern for the environment. Therefore, it requires good cooperation between formal and informal educational institutions. This is in accordance with the findings stated by Tamara [3] that the formation of student character does not only occur in the classroom/school but also occurs in the community/peer environment; especially family who plays a role in character building. More deeply, according to Mustika [4], character building does not only occur in the family and community environment, but also in the school environment in which teachers or lecturers must play an active role in changing the mindset of students who are environmentally friendly, especially geography students who are closely related to the environment.

An important aspect that geography students must have been to utilize the environment as wisely as possible by prioritizing the three main elements of geography: spatial, environmental, and territorial. Geography education students must possess three aspects because every discussion is always explained using environmental, territorial, and spatial perspectives. Geography learning aimed to minimize the insensitive attitude towards the surrounding environment.

Based on the above statement, the researchers are interested in researching the role of the family environment in building the environmental care character of Universitas Samudra geography students. Character development should incorporate the intellectual, emotional, and spiritual aspects. It is obtained mainly from family education. Awareness of the students' environmental care is part of the character that grows by it based on the emotions formed from the habits of students.

It is reinforced by Rohana's [5] statement that building complete human resources, in essence, is the development of character and superior human character from the intellectual, emotional, and spiritual aspects that can actualize the dimensions of intellectual, emotional, and spiritual intelligence holistically in the life. Another argument is based on Magda's [6] research that environmental awareness is expected to be a part of the characters of young people. This current research aimed to determine how big the role of the family environment is in building the care character of the geography students of Universitas Samudra. The results are expected to add insight to readers, further researchers, and the world of education regarding the role of the family environment in building students' environmental care character.

\section{METHODS}

The location of this research is in Langsa, specifically at Universitas Samudra. Treatment was given to both students and parents. This study uses a quantitative descriptive model. This descriptive research investigates phenomena that occurred in the object of a study. This research employs survey methods, questionnaires, and interviews. The populations of this research were all students of the Faculty of Social and Political Sciences at Universitas Samudra. The sampling method used was proportionate stratified random sampling. There were 20 respondents from the Faculty of Teacher Training and Education at Universitas Samudra who participated in this research. The variables used are the role of the family environment $(\mathrm{X})$ and building the character of caring for the environment of students (Y). The questionnaire in this study was designed to measure each variable. Each variable is measured using a labelled scale. Furthermore, the researchers processed the variables from the results of the answers to the questionnaire distribution to students to process the data using descriptive percentages [7]

\section{RESULTS AND DISCUSSION}

The family environment greatly influences the formation of the moral foundations of students for the development of their personalities. Therefore, the role of the family is very important in changing children's behaviour. The attitude of caring for the environment [8] of geography students will be well-formed if the family environment maximally builds positive moral values from a child at an earlier age so that a character that is inherent in the child will be formed from an early age. The instrument used to measure the role of the family environment in building the character of caring of Geography students at Universitas Samudra students can be seen from the following indicators: (1) participation of the family; (2) inculcating environmental care character values; (3) The pattern of life in the family.

\section{A. The Role of the Family in Building the Environmental Care Character of Geography Students Based on the Participation in the Family Environment}

Based on the score calculation, the maximum score for the category of family environment participation is $75 \%$, and the minimum score is $55 \%$, with a total achievement rate of $94 \%$. The total mean score and the level of achievement figures indicate that the role of the family environment regarding family participation in building the character of geography students is quite good. The distribution of frequency can be seen on the following figure 1 :

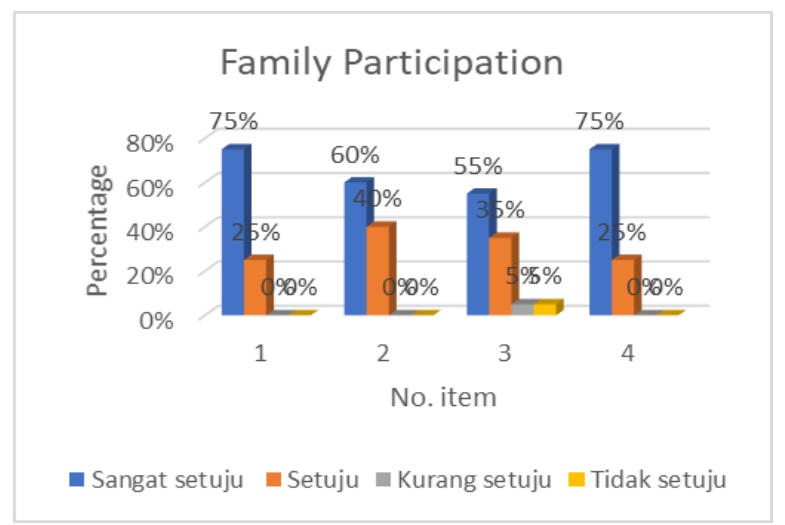

Fig. 1. The histogram of the frequency distribution regarding the role of the family environment in the category of participation in the family environment in building the environmental care character of geography students. 
From the results of the data analysis, the parameters of the role of the family environment in the category of participation of the family environment in building the character of caring for the environment of geography students, it is known that there is a good frequency. By referring to the indicators of the role of the family environment, the category of participation in the family environment has a positive effect on the formation of the character of the environmental care of geography students. This is due to the direct involvement of parents in instilling and guiding respondents in simple things at home such as disposing of garbage in its place, carrying out cooperation in the family environment, placing items in their place, and maintaining the cleanliness of the environment around the house. It can be concluded that the participation of the family environment provides an effective role in building the character of caring for the student environment.

\section{B. The Role of Family Environment in Building the}

Environmental Care Character of Geography Students

Based on the Category of Inculcating the Value of Environmental Care Character

The role of the family environment in the category of planting the character values for environmental care can be distributed based on the results of data processing from research instruments distributed to 20 respondents. The maximum score for the category of character value for environmental care is $80 \%$, and a minimum score is $50 \%$, with a total achievement rate of $95 \%$. The total mean score and the level of attainment figures indicate that the role of the family environment in the category of environmental care character values for geography students is good. The frequency distribution is presented in the following histogram:

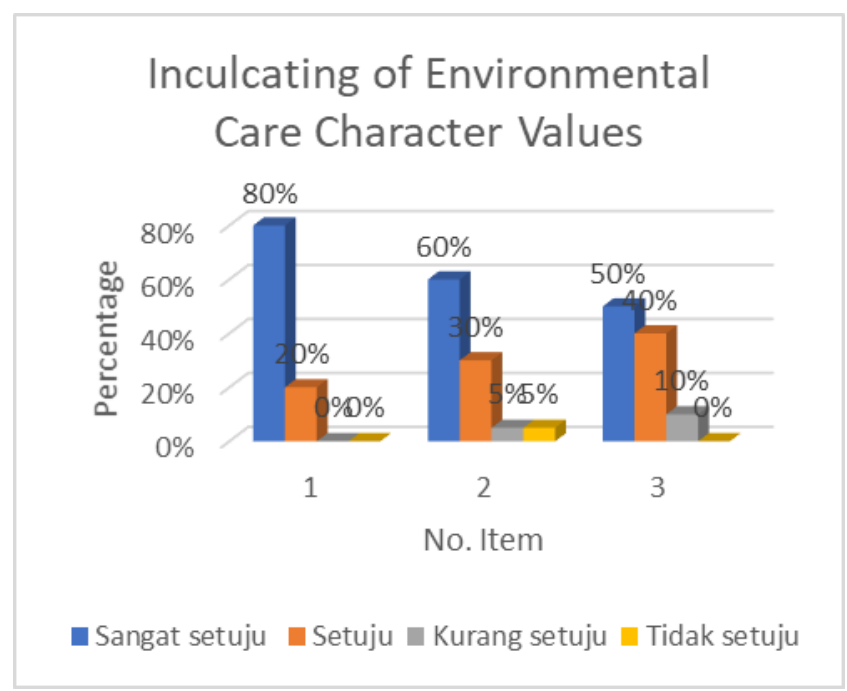

Fig. 2. The histogram of the frequency distribution regarding the role of the family environment in the category of environmental care character value cultivation in building the character of environmental care of geography students.

From the results of data processing, the parameter of the role of the family environment in building the character of environmental care of geography students viewed from the category of planting the value of care character for the environment are known to have a high frequency. If we refer to the indicator of the role of the family environment in the category of planting the character values of caring for the environment, this is because the family instils moral values in children from an early age, so that children are accustomed to doing positive things such as maintaining cleanliness and disposing of garbage in its place. Building the environmental care character of students from their families is shown by the enthusiasm of all students participating in planting 1000 trees in the Kuala Langsa community.

\section{The Role of the Family Environment in Building Environmental Care Character of Geography Students Based on Family Lifestyle Category}

Family is the main factor in shaping student character. The positive or negative character of children from an early age depends on the pattern of family life. A good family life pattern will make the character of the nation's children with positive morals. Based on the results of data processing from the instrument, the maximum score is $65 \%$, and the minimum score is $45 \%$, the mean score with a total achievement level of $91 \%$.

The total mean score and the level of achievement figures indicate that the role of the family environment in building the character of caring for the environment of geography students in the category of family life patterns is quite good. The following histogram shows the frequency distribution:

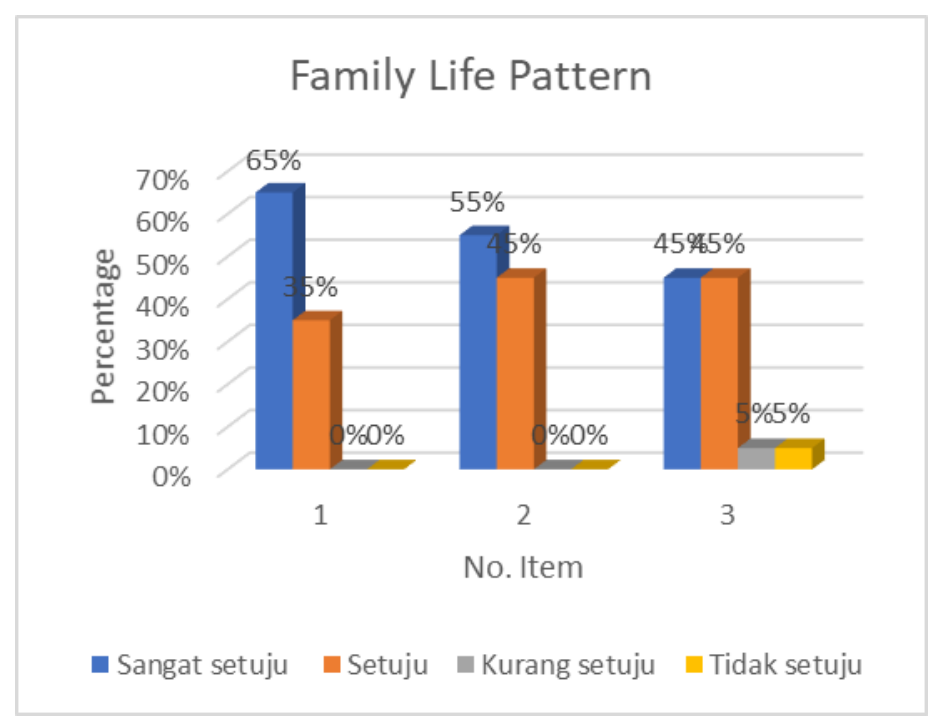

Fig. 3. The histogram of the frequency distribution regarding the role of the family in the category of family life patterns in building care character of geography students.

From the results of data processing, the role of the family environment, specifically family's life pattern, in building the character of caring of has a lower frequency compared to other two categories: inculcating the character values of caring for 
the environment and participation of the family environment. This is due to the level of parents' busyness with work so that children and parents do not interact with them enough and are even neglected. This finding is in line with the results of interviews with the parents who revealed that the activity of earning a living with the family diminishes interaction with children, even meeting only from dusk to morning. Rest time at night reduces the intensity of intimacy between children and parents.

The family environment consists of several categories, covering the participation of the family environment, the inculcation of character values of caring for the environment, and the pattern of family life in building the environmental care character of geography students of Universitas Samudra. It is indicated through the results of questionnaire distribution answers.

Based on table 1, it can be seen that the percentage of integration of environmental care character values through the role of the family environment according to respondents as students is the inculcating of environmental care character values by parents to students in the category of family environmental participation with the highest percentage score of $94 \%$, the category of inculcating environmental care character values got the highest score at $95 \%$, while in the category of family life patterns with a percentage of $91 \%$. This finding is based on the results of interviews with several respondents and parents that in the category of inculcating the environmental care character values got the highest score because in building good moral values to children, parents often teach simple things such as routine mutual cooperation every week in the home environment, for instance, placing goods in the proper place, throwing garbage in the trash bin, and throwing garbage at garbage dump provided by local government.

The following are the answers to questionnaire distributed to the respondents.

TABLE I. THE ROLE OF THE FAMILY ENVIRONMENT IN BUILDING THE ENVIRONMENTAL CARE CHARACTER OF GEOGRAPHY STUDENTS OF UNIVERSITAS SAMUDRA

\begin{tabular}{|l|l|l|}
\hline No & \multicolumn{1}{|c|}{ Role of the social environment } & Percentage \\
\hline 1 & Participation in the family environment & $94 \%$ \\
\hline 2 & Participation in the family environment & $90 \%$ \\
\hline 3 & Participation in the family environment & $85 \%$ \\
\hline 4 & Participation in the family environment & $94 \%$ \\
\hline 5 & Inculcating the value of environmental care character & $95 \%$ \\
\hline 6 & Inculcating the value of environmental care character & $86 \%$ \\
\hline 7 & Inculcating the value of environmental care character & $85 \%$ \\
\hline 8 & Family lifestyle & $91 \%$ \\
\hline 9 & Family lifestyle & $89 \%$ \\
\hline 10 & Family lifestyle & $83 \%$ \\
\hline
\end{tabular}

From the results of data analysis, it can be obtained that the parameters of the role of the family environment in building the environmental care character of geography students have different frequencies. Overall, it can be concluded that the most important role in building students' environmental care character lies in the category of inculcating the values of environmental care character with the highest total score of 95\% that can be categorized as good. Meanwhile, the family lifestyle category has a minimum percentage compared to other categories with a total score of $91 \%$.

Similar research results [9] The results showed that there is a significant correlation between living environmental knowledge with environmental care character. Based on each category of the role of the family environment, it must work together to strengthen and complement the three categories in building the values of environmental care character of geography education students. Inculcating character values may support environmental issues [10]. This will produce educated and moral children from the informal education provided by the family.

\section{CONCLUSION}

The conclusion of this study is that the role of the family environment is important in building the environmental care character of geography students of Samudra University. The role of the family environment has each category with a different total score achievement, such as the category of family environment participation in building environmental care character of geography students get a total maximum score of $75 \%$, then the category of inculcating the values of environmental care character with a maximum score of $80 \%$, and the category of family lifestyle has a maximum score of $65 \%$. It can be interpreted that the category of inculcating the values of environmental care character has a good frequency in building the environmental care characters of geography students.

\section{REFERENCES}

[1] N. Naim, Character Building Optimalisasi Peran Pendidikan dalam Pengembangan Ilmu \& Pembentukan Karakter Bangsa. Jakarta: ArRuzz Media, 2012.

[2] D. Purwanti, "Pendidikan Karakter peduli Lingkungan Dan Implementasinya,” DWIJA CENDEKIA: Jurnal Riset Pedagogik, vol. 1, no. 2, pp. 14-20, 2017.

[3] R.M. Tamara, "Peranan lingkungan sosial terhadap pembentukan sikap peduli lingkungan peserta didik di SMA Negeri Kabupaten Cianjur," Jurnal Geografi Gea, vol. 16, no. 1, pp. 44-55, 2016.

[4] F. Mustika T.M. Sahudra, "Peranan Lingkungan Sosial terhadap Pembentukan Karakter Peduli Lingkungan Mahasiswa Pendidikan Geografi di Universitas Samudra Langsa,” JUPIIS: Jurnal Pendidikan Ilmu-ilmu Sosial, vol. 10, no. 2, pp. 235-244, 2018.

[5] E. Rohana, "Character Education Relation With Spiritual Intelligence In Islamic Education Perspective," International Journal of Nusantara Islam, vol. 6, no. 2, pp. 165-174, 2018

[6] M.M. Pane and R. Patriana, "The significance of environmental contents in character education for quality of life," Procedia-Social and Behavioral Sciences, vol. 222, pp. 244-252, 2016.

[7] S. Sugiyono, Metode Penelitian Administrasi dilengkapi Dengan Metode R\&D. Bandung: Alfabeta, 2016

[8] S.W. Handayani, "Pembentukan karakter peduli lingkungan sejak din melalui program konservasi TAOBAT di TK Labschool UNNES," In 
Prosiding Seminar Nasional Pendidikan Biologi, vol. 43, no. 6, pp. 7680, 2018.

[9] R. Ahmadi, A. Surbakti and T. Jalmo, "Hubungan Pengetahuan Lingkungan Hidup dengan Sikap Peduli Lingkungan Hidup," Jurnal Bioterdidik Wahana Ekspresi ilmiah, vol. 6, no. 2, pp. 2521-559, 2018
[10] F.L. Hebel, P. Montpied and V. Fontanieu, "What Can Influence Students' Environmental Attitudes? Results from a Study of 15-year-old Students in France," International Journal of Environmental \& Science Education, vol. 9, no. 3, pp. 329-345, 2014. 